\title{
Maternal response to neonatal sibling conflict in the spotted hyena, Crocuta crocuta
}

\author{
Paula A. White
}

Published online: 10 July 2007

(C) Springer-Verlag 2007

Erratum to: Behav Ecol Sociobiol

DOI 10.1007/s00265-007-0422-2

A typographical error was made during the publication of the above article. The correct name of the author is Paula A. White.

The online version of the original article can be found under doi: $10.1007 / \mathrm{s} 00265-007-0422-2$.

P. A. White $(\bowtie)$

Museum of Vertebrate Zoology, University of California,

3101 Valley Life Sciences Building,

Berkeley, CA 94720, USA

e-mail: PAW@carnivoreconservation.com 